1. 最高耐熱点は成熟度にしたがつてょり高くに転移し

2. 最良の HS 効果のための受熱感度適量は一般に最高酎熱点より低く、これも成熟度にしたがつてより高く 沈ざれ

3. 旺盛に酸酵する細胞群をえるためには，成熟度と受熱量との相関で求められる受熱感度最適点が存し． Clostridium acetobutylicum 314 では成熱度については培養中大部分の細胞が避離胞子になつた時が最適で, 約 半数が clostridia になつた時期がこれにつぐことが明かにされた。

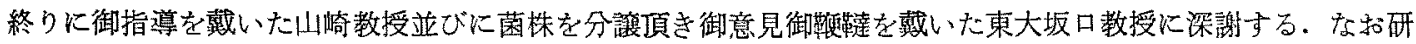
究費の一部は文部省科学研究㙺による.

(1) S. C. PRESCOTT, C. G. DUNN : Ind. Microbiol., 320 (1949).

(2) E. R. WEYER, L. F. RETTGER 14, 399 (1927).

(3) 土井新次, 山田武雄 : 本誌, 16,985(1940).
(4) D. R. GODDARD, P. E. SMITH Physiology, 13, 241 (1938).

(5) 本江元吉 : 本誌, 24, 119 (1951).

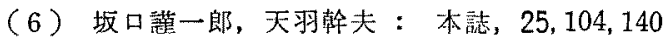
(1951).

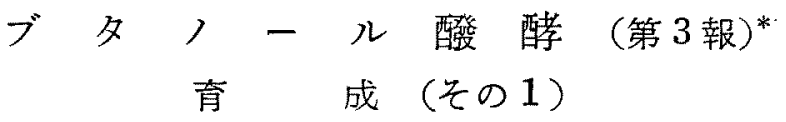

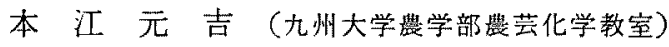

昭和 31 年 6 月 18 日受理

ブタノール菌株取报い上の特徴の1つは所謂育成である。これらの菌株は環境の酸化還元電位的影響や培地の 栄盖源的影響に鋭敏に感応する．それは前報(1)した胞子の発茅や細胞の生育でだけではなく，酸酵でも酸醉速度

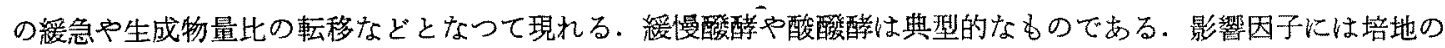
緩衝能の不足や酸酵正常化物質の欠減, 雑菌やバクテリオファージの污染, 或は種母の生理的不良なとがある. この5ち種母の状態を良くして酸醳の異常化を避け出来るだけ酸酵速度を增すこと，その上らな種母を仕立てる こと,を育成とい5.

これらの菌株では強いことと酸酵力が旺盛であることとは必ずしも一致しない. Heat shock (以下 HS と略)

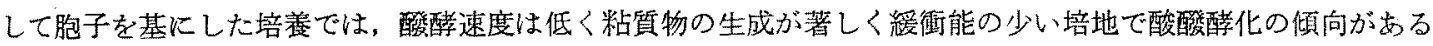
反面，紐胞のブタノール抵抗性怯大で糖消費率も高く，所謂強いという表現にあてはまる。一方，これからHS

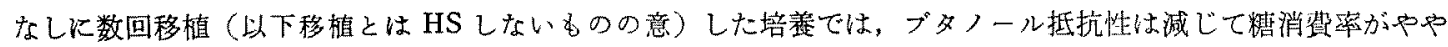

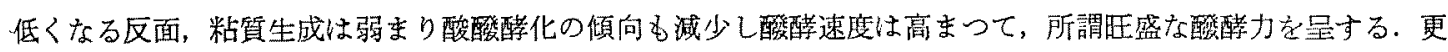
に移植を続けると湧き付きは早いが酸醉速度は却つて低くなつて酸醉は緻慢になり時には中緦するなど極端に弱

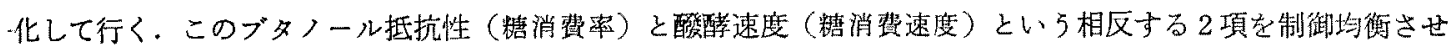
て最適点を主酸醉に求めるのが育成の一要点となる。

種母の生理について检せられていたのは(2 16)，胞子から出発して何回移植した培盖を使壳ばよいかといろこと そ，主酸醉直前の培盖でどの時期に接種に使兄ばよいかということとであつた，前者については，檓粉質の酸

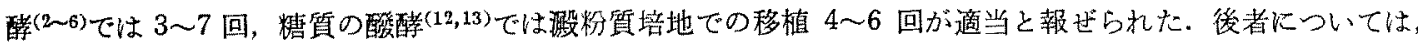

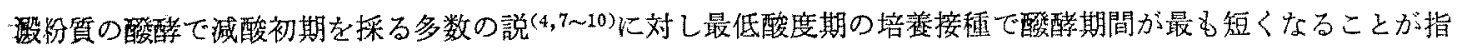

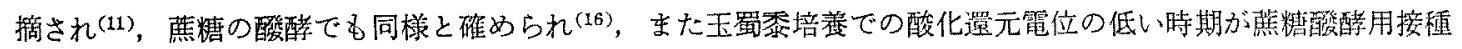
比良好と報ぜられた(15). 奇少にる移植回数と接種時期との相関で最適点を求めよ5とする試み快全く行われず， 前者では一律に 24 時間每の移植が行われ, 後者では単に主酸醏直前の培荃でだけその接種時期の影響が検せら れていた。一方, 蕉糖酸醉では特殊の育成法が呈示されていた(17).それは緩衝能の少い蕉糖培地での酸酸醉中絶

* Butanol Fermentation. Part III. A Technique of Inoculum-development Method ( 1 ). By Motoyoshi HoNgo (Department of Agricultural Chemistry, Faculty of Agriculture, Kyushu University) 


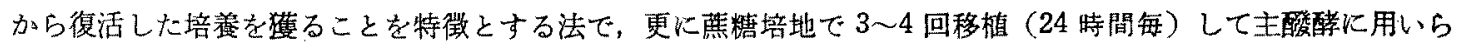
れた.

以上の諸法を检討し，移植の時期と代数との相関的な影響を検して，育成技法に指針を得るために，以下の実

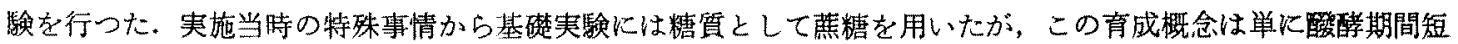

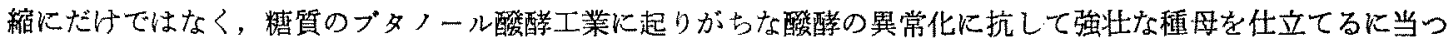
ても，まだ新菌検索に際して分離菌株の性能試験に当つても，常に梁く留意しなければならない処であるので，

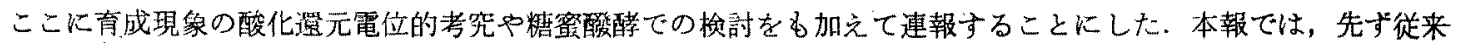
法の検討及び以後の実験の方法的基磷となるガス出量と酸度変化との関係について報ずる.

実

験

\section{I. 使用菌株}

東大 314 及び 179. 两株共 Clostridium acetobutylicum (WEIZMANN) MCCOY, FRED, PETERSON et HASTING に虽する．前報(1)の上にに前者は純一性の保証されたもの，後者には好気性菌が混在する。

\section{II. 促来諸法の検討}

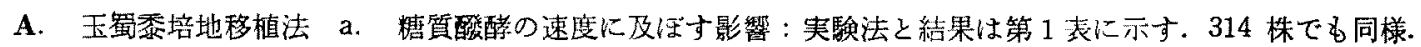

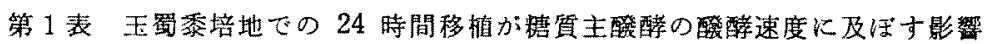

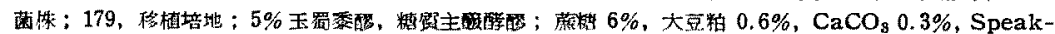

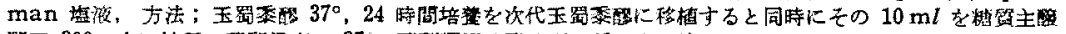

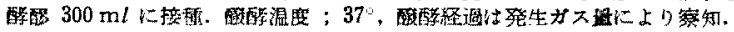

\begin{tabular}{|c|c|c|c|c|c|c|}
\hline 種母移植 & & 魹 生 & 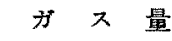 & \multicolumn{3}{|c|}{$\mathrm{g} / 300 \mathrm{ml}$ （）内汒合 } \\
\hline 回 数 & 1 & 2 & 3 & 4 & 5 & $5 \mathrm{HS}^{*}$ \\
\hline $\begin{array}{l}\text { 睽 } \\
\text { 醉日 } \\
\text { 間 }\end{array}$ & $\begin{array}{l}1.90 \\
3.30(5.20) \\
2.12(7.32) \\
2.45(9.77) \\
0.83(10.60)\end{array}$ & $\begin{array}{l}2.40 \\
3.27(5.67) \\
2.73(8.40) \\
2.07(10.47)\end{array}$ & $\begin{array}{l}2.23 \\
3.69(5.92) \\
2.73(8.65) \\
1.73(10.38)\end{array}$ & $\begin{array}{l}2.07 \\
4.75(6.82) \\
3.20(10.02)\end{array}$ & $\begin{array}{l}2.19 \\
5.43(7.62) \\
2.37(9.99)\end{array}$ & $\begin{array}{l}0.60 \\
2.22(2.82) \\
4.17(6.99) \\
2.30(9.29) \\
1.46(10.75)\end{array}$ \\
\hline
\end{tabular}
ソルベンั 33.6
34.6
35.6
36.2
35.0
32.0

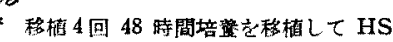

第 2 表 蜀霍培地での 24 時間移植が糖質主瞪睹の強さに 及ほす影翟

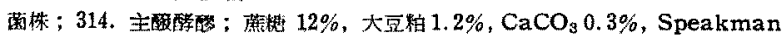

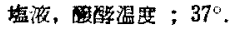

種母移植回数

1

5

接理徒時間

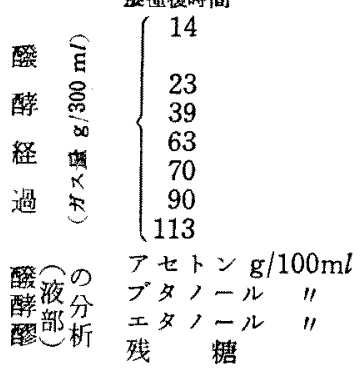

0.57

2. $84(3.41)$

4. $73(8.14)$

$6.49(14.63)$

4. $93(19.56)$

1. $65(21.21)$

$\begin{array}{ll}1.06 & 1.09\end{array}$

$\begin{array}{ll}1.44 & 1.25\end{array}$

$0.29 \quad 0.50$
1. 36

4.32(5.82)

11. 58(17.40)

2. $79(20.19)$

1. 14

即ら，いすれれ正常 䣹䤃，従来示された 上了炡初 4 5 日 を要した酸酵期間は 4〜5回移植で 3 日 前後に短縮される。 また移植を経るに従 つて発生ガス全量は やや減ずるが，これ をHSすると期間及 びガス鼻は旧に復する.多数の検討中時に は2日余りで終了することもかるが常には 期符できない：また移植何回目に最短のむ。 のが表われるが不明で偶発的である。

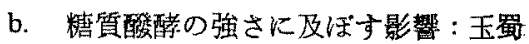
黍培地で移植 1 回の培養と 5 回の培盖とを 種母にした菣情酸醭の狙弱性を比較. 差を 曊著ににするため $12 \%$ 䅺濃度酸 $(300 \mathrm{ml})$ 厄行い接種後 14 時間目に活性炭添加. 分 析は液部についてのみ第 2 表に示す（活性

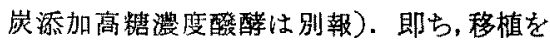
経たものは酸酵速度は增すがブタノール抵。

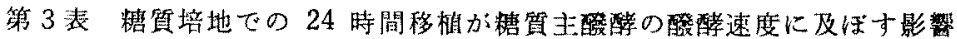

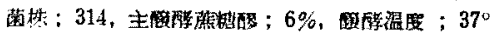

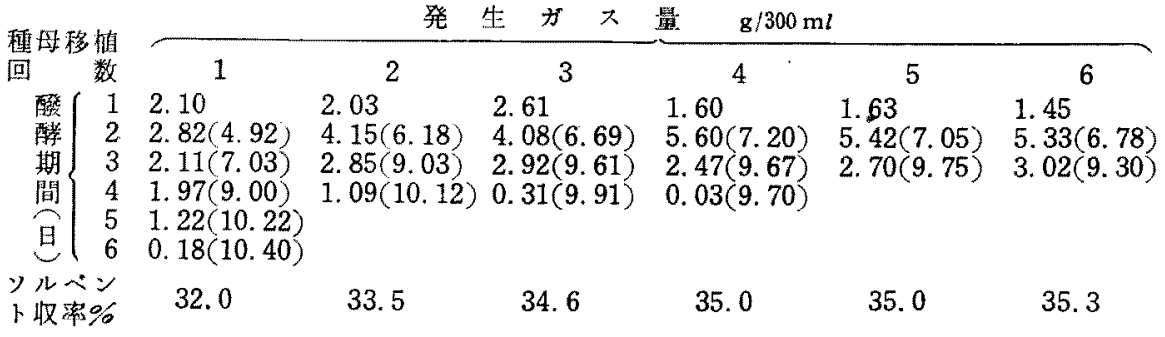
抗性は搦化し液中生 成ブタノール湄度は 低く残精が多くなる。

B. 諩質培地移植 法 或基質代謝実殹 で，同基質含有培地 に使用菌株を铝り返 し移植培裳してその 基質代謝能を增させ 
上うとする所謂馿養は，菌学領域で普通に試みられる処である．検討のため，移植を主酸酵と同一組成の蕉糖培 地 $10 \mathrm{ml}$ で行つた。結果は第 3 表に示す。この例は最も普通に表れるもので時には $4 \sim 6$ 回移植でも 4 日に及 ぶ. 179 株で同様. 即ちこの操作では酸酵速度增加の効果は玉蜀愁培地で移植するのと同等或はそれ以下であ つて，酸醉期間の短縮は生細胞の移植に基くものであり糖質への郮養の効果が表れるものとは認められない。

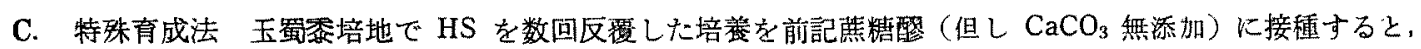
涌き付いた酸醳は緩衝能不足のためやがて中絶する．これに極少量の $\mathrm{CaCO}_{3}$ を添加すると再ひ酸醉し始める. 酸醉が旺盛となる時へッド部半量液部半量の割に $10 \mathrm{~m} l$ を採り，蕉糖酸 $300 \mathrm{ml}$ に接種し $\mathrm{CaCO}_{3} 1 \mathrm{~g}$ を源加， 以下 24 時間移植を継続する. 結果は第 4 表に示す. 179 株でもほぼ同様. 即ち, 移植 3〜5 回で $2 \sim 3$ 日間で

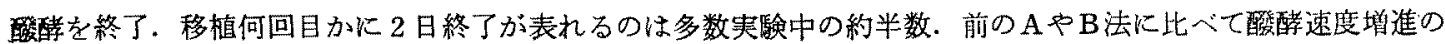
第 4 表 特 殊 育 成 法

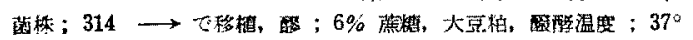

$$
\text { 発生 } t^{2} \text { 万量 } \mathrm{g} / 300 \mathrm{~m} l
$$

\begin{tabular}{|c|c|c|c|c|c|c|}
\hline $\begin{array}{l}\text { 種母移 } \\
\text { 湘回数 }\end{array}$ & $\mathrm{CaCO}_{3}$ 無添加 & 1 & 2 & 3 & 4 & 5 \\
\hline 1 & 1.36 & 2.03 & 2.95 & 4. 13 & 3.70 & 4.55 \\
\hline \multirow{3}{*}{$\begin{array}{ll}\text { 酸 } & 2 \\
\text { 醇期 } & 3 \\
\text { 間 } & 4 \\
& 5\end{array}$} & \multirow{3}{*}{$\begin{array}{c}0.67(2.03) \\
0.05(2.08) \\
\mathrm{CaCO}_{3} 0.4 \mathrm{~g} \text { 添加 } \\
0.18(2.26) \\
0.83(3.09)\end{array}$} & $3.28(5.31)$ & $5.60(8.55)$ & $5.50(9.63)$ & $6.24(9.94)$ & $4.35(8.90)$ \\
\hline & & $2.20(7.21)$ & 1. 10(9.65) & $0.30(9.93)$ & & $1.33(10.28)$ \\
\hline & & $2.13(9.64)$ & & & & \\
\hline
\end{tabular}

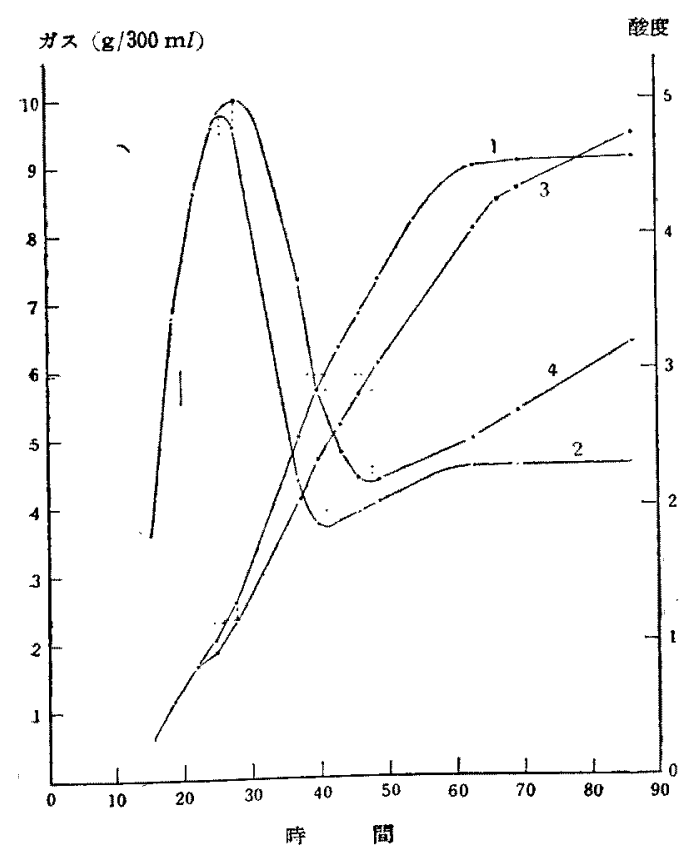

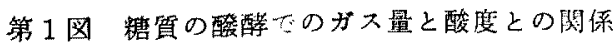

（a）酸酵速度の增進していない培養（玉蜀䨑 HS 培養接種)

1: 314 梾ガス喵紭

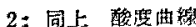

3: 179 梌ガス曲鼣

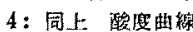

36.4

35.4

35.8

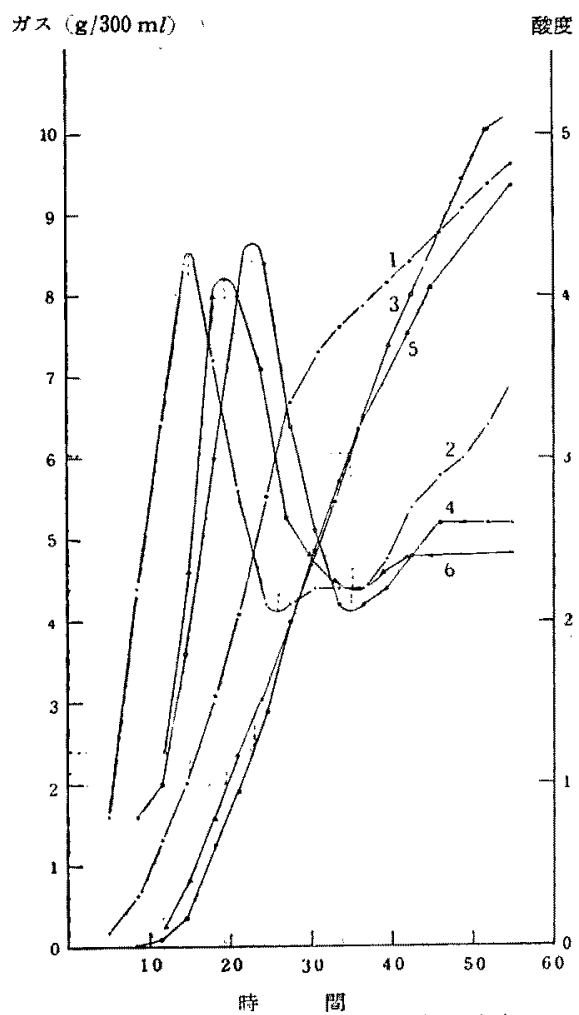

第 2 図糖質の醴酵でのガス量と酸度との関係 (b) 酸酵速度の增進している培稳（移植数回

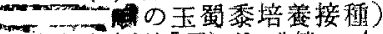

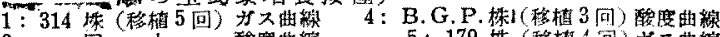

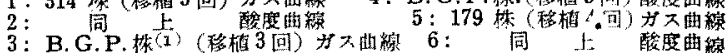




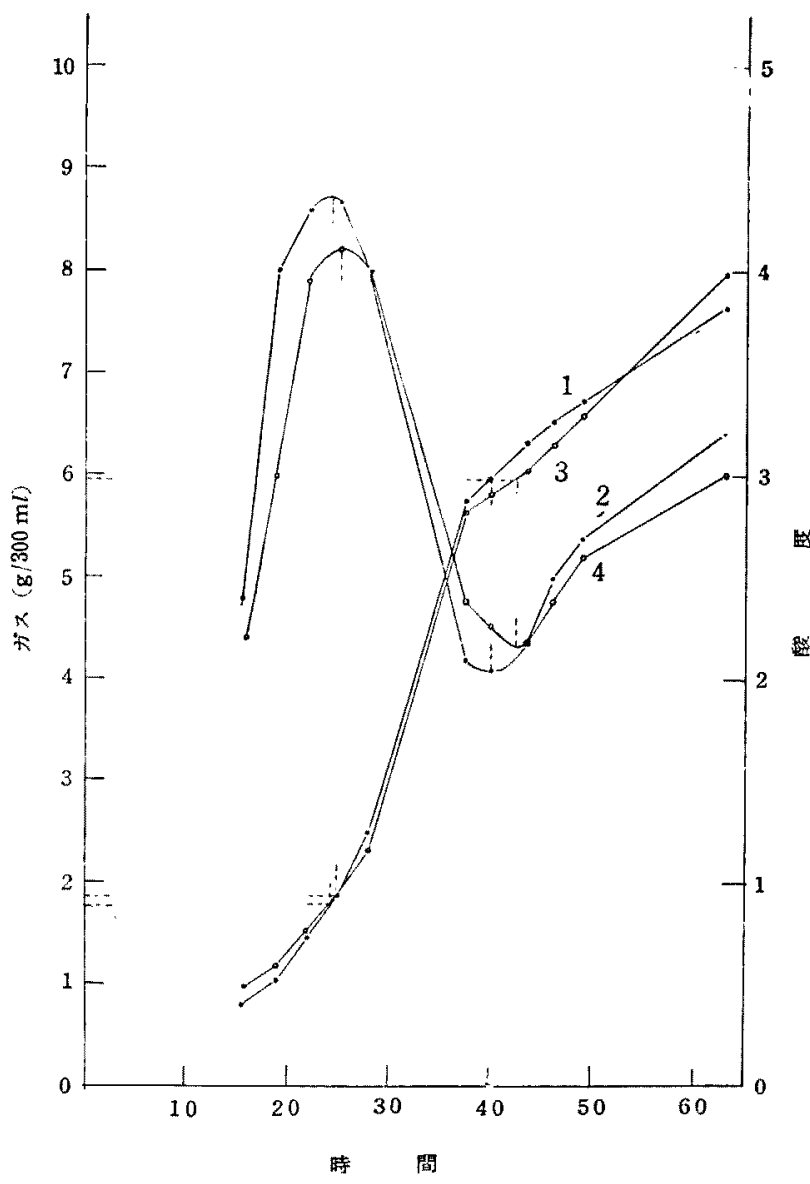

第 3 因王蜀霖の醴酵てのガス量と酸度との関係

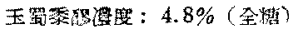

1: 314 株（移植 3 回） ガ又仙線

2: 同上和

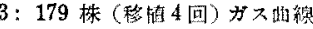

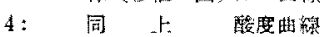

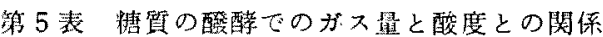

(c) 高糖婊度 $(12 \%)$ 培道

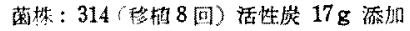

$\begin{array}{lccccccc}\text { 培羕时间 } & 13 & 17 & 20 & 23 & 25 & 46 & 90 \\ \text { 酸度 } & 4.70 & 4.30 & 3.60 & 2.60 & 2.20 & 3.00 & 3.20 \\ \text { ガス量 } & 2.10 & 3.11 & 4.29 & 5.59 & 6.45 & 9.83 & 20.50\end{array}$

効果はより大であるが，それがこの酸酸醳を 释る特殊操作にのみ起因するとするには，移 植回数の少い培期での酸間が両法に比へ て短繀されていないことに不碓かさが岕り， また移植にへッド半量液半量の割に種母を採 るのは，常の移植に比べる，著しくへッド が多く種母細胞を極めて多数に接種したこと になり，そのために表れた効果と歹考光られ る.つまり本法の特徵である当初の酸酸酵を 経る操作はブタノ一ル生成系の発現と機能と を確実にすることにあるとみられ，その後の 酸醭速度の增進はより多量の細胞移植による 効果と一応考学られる. 然しこの点について は再检を要寸る.本法でる一連の移植の中で

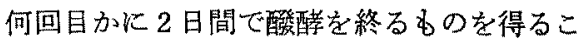
とを常に期待することは困難であり，また移 植何回目に最短酸酵期問のものが表れるが 不明で偶発的である。

\section{III. ガス量と酸度との関係}

従来の諸法では，どれる移植を時間できめ て培意経過の時期には注意が払われていなか つた。ここの種母の生理状態についてはただ主 酸醉直前の培養だけに対して源定酸度或は酸 化還元電位を示絮として考慮されていた，酸 度は測り慣れており工場ではこれによつてい たが，実験室では煩雑で科量ですむガス量測 定が便利であつた。然し雨者の関係は検討さ

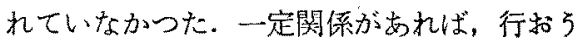
とする育成技法检䣓に実験操作が簡易化され

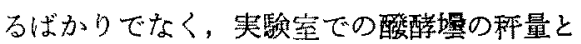
工場での鋯の酸度滴定とが結びつけられるの で諸種の操作や推論にもたらされる利点は少 くないと考觉られた。それで，糖質及ひ澱粉

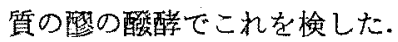

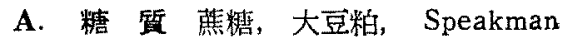

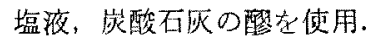

a. 䀧酵速度の增進していない培着：第 1 図に示す。

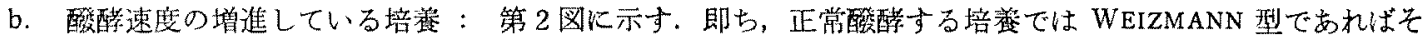

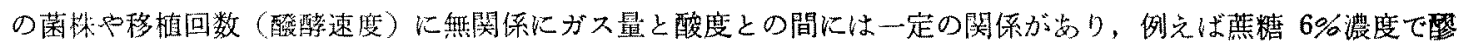
$300 \mathrm{ml}$ 当りガス量 $2 \mathrm{~g}$ 前後が最高酸度期に， $6 \mathrm{~g}$ 前後が最低酸度期に相当する.

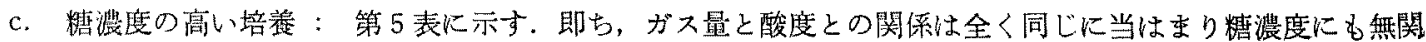

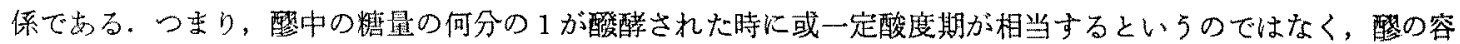
量に対なるガス量（培盖の単位容量当りの消費糖量）で酸度期が推定できる。

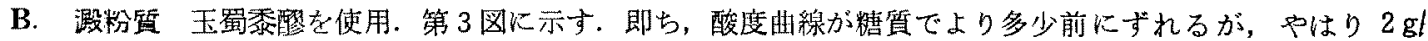
$300 \mathrm{ml}$ 足らずが最高酸度期, $6 \mathrm{~g} / 300 \mathrm{ml}$ 足らずが最低酸度期である。 


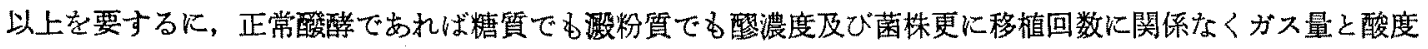
との間に一定関係が認められた。従つて実験室的には簡便な科量によつて酸度期が察知され，またこの実験室的 結果を酸度によつて工場的操作に移寸ことができることが明かになつた（単位時間当りのガス量と酸度との関倸 は酸化摆元電位との関係を附して後報する).

総 括

1.ブタノール酸酵の種母仕立てに際して, 菌の生理状態に留意して異常化を防止し, 互に逆の傾向にある糖 消費の率と速度とを制御均衡させて最適点を主酸醉に求めることを育成という。

2. この有成について従来呈示された諸法を検討し，そのいずれるが推測的であることを指摘し，技法につい ての盲点の 1 つは 2 因子をなす移植回数と移椬時期とを結びつけた検討がなかつたことであると示した.

3. 技法榆討の利便のため, 発生ガス量と滴定酸度との関係を検し, その間に一定関係があり, 各酸度期に対 応するガス出量は培盖容量によつて規制され，菌株，基質，糖濃度及び酶酵速度によつて左右されない(例えば 最高酸度期及び最低酸度期は酸 $1 l$ 当りガス出量それぞれ $6.6 \mathrm{~g}$ 前後及び $20 \mathrm{~g}$ 前後に対応する）ことを明かに した.

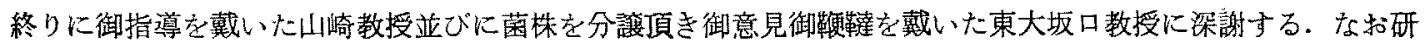
究費の一部は文部省科学研究費による.

(1) 本江元吉： 本誌, 24, 119 (1951).

(2) H. B. SPEAKMAN : Ind. Eng. Chem., 12, $581(1920)$.

(3) E. R. WEYER, L. F. RETTGER $J$. Bact., 14, 399 (1927).

(4) D. A. LEGG : U.S. Pat. $1,668,814(1928)$.

（5）湯川又夫, 堀江重美本誌, 15,609(1939).

(6) C. M. Artigas, A. M. Jané C. A., 44, $5060(1950)$.

(7) 土井新次, 山田武雄 : 本誌, 16, 935(1940).

（8）朝井勇宣, 小島隆吉, 渡辺勇 : 本誌, 17, 959 (1941).

（9）大谷昌久 本誌，16，985(1940).
（10）樋田秀雄，曾和德雄等： 本誌， $18 ， 785$ (1942).

（11）井上七雄 : 本誌, 20, 74 (1944).

(12) L. A. UNDERKOFLER, L. M. CHRISTENSEN, E. I. Fulmer : Ind. Eng. Chem., 28, 350 (1936).

（13）山崎何惠：罡化大会講 (1939).

(14) H. D. SEN, B.C. Joshi C. A., 37,6082 (1943).

（15）星野一婎 本誌, 19, 405 (1943).

（16）杉山正雄, 川野義雉, 長瀬俊三郎 酸工, 23, 12 (1945).

（17）山崎何惠：九大化学集談会講演 (1942). 